European journal of American studies

Special Issue: Video Games and/in American Studies:

Politics, Popular Culture, and Populism

\title{
Feasts of Indifference: Racialization, Affect, and Necropolitics in 1X War Games
}

Mahshid Mayar

\section{(2) OpenEdition}

\section{Journals}

Electronic version

URL: https://journals.openedition.org/ejas/17374

DOI: $10.4000 /$ ejas. 17374

ISSN: 1991-9336

Publisher

European Association for American Studies

Electronic reference

Mahshid Mayar, "Feasts of Indifference: Racialization, Affect, and Necropolitics in 1X War Games", European journal of American studies [Online], 16-3 | 2021, Online since 10 September 2021, connection on 17 September 2021. URL: http://journals.openedition.org/ejas/17374 ; DOI: https://doi.org/ 10.4000/ejas. 17374

This text was automatically generated on 17 September 2021

Creative Commons License 


\title{
Feasts of Indifference: Racialization, Affect, and Necropolitics in 1X War Games $^{1}$
}

\author{
Mahshid Mayar
}

\section{Introduction: Enmification, or the Logic of Hostility in Digital Games}

1 Since at least the Cold War period, the publicly consumable renderings of political or ideological enemies of the United States in the fictive expanse of US popular culture have resulted in a long list of enemy types that are constructed by a culture that imagines itself at constant war with infinite waves of adversaries. Indeed, the way the ideological enemy of the Cold War was replaced by a (dis)similar ideological enemy in the wake of the $9 / 11$ events reflects, at least in part, "the ease with which Americans feel comfortable having a foreign enemy, somewhere out there, ready to threaten the American way of life" (Wiegand 52). In this vein, construed as an aggressive, ultimate Other, an inversion of American selfhood, an entity that threatens Americans' survival and well-being in an immediate, undeniable, at times lethal manner, America's newest enemy has been constructed and called upon as an extreme form of Other. Since 2001 (but also earlier than that), this new enemy is a conveniently makeshift, yet convincingly make-believe evil force that has to be fought against in countless real and virtual wars. ${ }^{2}$

2 As digital, ludic battlefronts of this persistent enmification mentality, digital war games have long created interactive settings in which old and new enemies of the United States are depicted either as universal, faceless enemies or as identifiable, racialized adversaries. On the one hand, video games present players with universal enemies of the US. These are interchangeable enemy forces that often appear in $4 \mathrm{X}$ strategy games where any and every group of people/nations/civilizations is a potential enemy. More recently, this also includes the cautiously de-racialized, nondescript enemies that 
players fight against in big-budget game franchises in which the enemy is an omnipresent, diffuse, and defaced entity. An example of unwinnable "anyone-can-bethe-enemy" games (Brady 88), the over-examined America's Army 3 (2009), for one, constructs a nondescript universal enemy, meaning that any and every group of nonAmericans can be, potentially, at war with the US army. At the same time, it is hard to overlook the fact that this amorphous construction further "betrays a sense of profound anxiety from an army that has lost the Cold War-era certainty about its enemy and the form its wars would take" (Schulzke 307).

Constructing interchangeable enemy forces within the safety of historical generalizations, 4X strategy games, such as Age of Empires (1997-2019) and Sid Meier's Civilization (1991-2016), present players with yet another universal enemy image. Rather than the more complex procedure of defacing and de-racializing the universal enemy, 4X games adhere to the old, agreed-upon, essentialized blueprint of colonization (cf. Robertson, "Unreal Enemy" and America's Digital Army). Woefully reductionist and ahistorical, they expand on a Eurocentric blueprint that entails a hurried hodge-podge of geopolitical exigencies, sociopolitical entanglements, and material culture that reduces the micro-historical complexities behind war scenarios to the basic four game-verbs "eXplore, eXpand, eXploit, and eXterminate" (Emrich 92). As gaming experiences develop around this diverse set of game-verbs, the so-called "essential four Xs of any good strategic conquest game" (Emrich 92), various exigencies -ranging from the civilization's need for resources, the players' desire to expand their civilization in space or strength, their tendency or reluctance to forge alliances, or the player's tolerance for proximity to an expanding exploitative neighbour-can turn any randomly assigned nearby civilization into an enemy.

On the other hand, included in this typology of enmification, and constructed in direct conversation with US foreign policy, are readily identifiable enemies (Nazis, Communists, Russians, or Muslims) who continue to appear as brutish, brutal, and crafty adversaries in first-person shooters and as despicable, under-armed forces in smaller shoot-'em-up war games. While larger games such as Delta Force (1998-2009), Spec Ops (1998-2012), Medal of Honor (1999-2012), Soldier of Fortune (2000-2007), and Call of Duty (2003-2019) have long crafted sophisticated, well-armed identifiable enemies as a branding strategy, smaller war games-what I refer to in this essay as $1 \mathrm{X}$ gamespromote only the last of the $4 \mathrm{X}$ game-verbs, that is to "eXterminate." Consequently, and this is the focus of the present essay, either hoping to offset their indifference to historical complexities and political tensions involved in the ludic frame of exploration, expansion, exploitation, and extermination or in an attempt to turn the game into an even more poignant critique of warfare in general, $1 \mathrm{X}$ games rely, rather heavily, on racialization of the enemy as the prime driving force of enmification as a move that gives sense to their crude scenarios of confrontation. In other words, rather than planning on how to negotiate territorial sovereignty and guard common borders with, encounter, negotiate, but also fight against the enemy, the choice that these games offer is to merely eliminate the already out-at-large, racialized enemy in a drone-like, distanced, and lacklustre manner.

$5 \quad$ As a result, small $1 \mathrm{X}$ games like the heavily criticized and deleted Muslim Massacre and the critically acclaimed, counter-narrative September $12^{\text {th }}$ end up promoting two radically different and yet equally non-immersive and highly political enmification projects that posit Americans against an imaginary Muslim enemy. In light of Amanda 
Phillips's re-reading of Achille Mbembe's notion of necropolitics, I examine these graphically simple, decidedly political, and controversial $1 \mathrm{X}$ games as titles that "entangle life, death, and play within a field of simulation" (Phillips 148). As I suggest below, taken together, September $12^{\text {th }}$ and Muslim Massacre put forward decidedly contrasting, yet usefully comparable approaches to enmification through racialization through entertainment-what, nodding to Sharon Patricia Holland (6), I understand as heedless feasts of indifference.

\section{2. "eXterminate," or Necropolitics in Gameworlds}

While comparing the directory of game-verbs in $4 \mathrm{X}$ and $1 \mathrm{X}$ war games, it becomes evident that "explore" and "expand" of $4 \mathrm{X}$ games primarily belong to a bygone, prepostcolonial (that is, colonial) order that historical digital games such as strategy games tend to reconstruct. The setting for $4 \mathrm{X}$ games is the time when the terra incognita ignited colonial imaginations and when mastery over the margins of power fueled expeditions. Yet, in the current post-terra incognita world of postcolonialism, explorations have already resulted in ever-detailed maps of all world regions, while acts of expansion have been attempted, foiled, or failed. In territory already explored and mapped, where the colonizer has already expanded its outreach, occupied and exploited culture and nature, all that is left to be done, $1 \mathrm{X}$ games seem to suggest, is to simply exterminate the undesirable, mapped out, known enemy. Now, Muslim Massacre and September $12^{\text {th }}$ target racially marked Muslim enemies with this very condensed arsenal of game-verbs, that is eXterminate, precisely because they are products of (and participating interlocutors in) a culture that belongs to the latest stage of the postcolonial, that is, the post-9/11 world order-an order increasingly defined by physical and spatial distanciation, reluctance, and ambivalence, but also confusion over what causes enmification or justifies "extermination."

7 Achille Mbembe has given us the conceptual frame within which we may make sense of the extremes of enmification that, in $1 \mathrm{X}$ games, translates to nonchalant simulations of projects of extermination. As Mbembe has it, "necropolitics" demystifies and yet weaponizes state power by zooming in on the politics of life (of some) through death (of others). A re-reading of Foucault's biopolitics in the wake of the so-called "war on terror," necropolitics builds on, and yet tears away from, the more classic understandings of the relationship between the state and the bodies of its constituents -on and off the battlefront. While dismissing the reasons behind enmification and leaving little room for the public to ask "why this enemy now?," the necropolitical sovereign decides on the order of life and death based on which it then proceeds to perform a legalized ritual of death-be it in the form of a national criminal justice system or a project of genocide and ethnic cleansing in near and far war theaters. This performance is scripted, Mbembe has it, in line with a primal binary that distinguishes between "those who must live and those who must die" (17).

Necropolitics works to both sway the public mood for wars and to fuel collective imaginaries as they give shape to public sentiments in favor of the sovereign's right to kill and rationalize the use of lethal force in eliminating its(/their) enemies. Now, an investigation of US popular culture through the lens of necropolitics enables us to make sense of extermination through ludification as not only the ultimate but also the most plausible result of the self-assigned, but popularly sustained, right of the 
sovereign to rule over human bodies. However, if necropolitics is about managing death in colonial (and postcolonial) slave plantations and in war zones in modern times, then, in what ways and how far can virtual gameworlds such as the ones built in two radically dissimilar $1 \mathrm{X}$ games such as Muslim Massacre and September $12^{\text {th }}$ reenact, perform, and comment on the necropolitical?

Responding to this judicious query and attending to the ways "the technological and the cultural" (137) entwine in digital games, Amanda Phillips proposes the use of "mechropolitics," a term that probes the representational work of the necropolitical state in the world of technology, such as in digital games. In her words, mechropolitics consists of "a virtual, often whimsical, politics of death and dying with complicated resonances in the real world" (138). In other words, mechropolitics enables the study of digital games to investigate death-politics in gameworlds not only in its mediatized and ludified forms but also-and this is crucial in looping back to Mbembe's historically informed observations on necropolitics across human communities-in relation to "real death worlds" (Phillips 139). In considering the necropolitical work of small, $1 \mathrm{X}$ digital games as machine-driven spaces where gaming is enabled through interaction with codes and mechanics, I adopt Phillips's conceptual lens, demonstrating the ways mechropolitics informs Muslim Massacre while it is drawn upon and then deflated-at least to some extent-in September $12^{\text {th }}$.

The heavily criticized and banned, 2D shoot-'em-up Muslim Massacre: The Game of Modern Religious Genocide (2008) was designed by Eric Vaughn, a freelance American game designer. Taken down amid massive online protests by Muslim and interfaith organizations and waves of underwhelming reception by game critics, it was banned and its website shut down. ${ }^{3}$ Even though Vaughn released a public apology on the net at the same time that he took the game down, Muslim Massacre eventually found its place, along with The Torture Game, Raid Gaza!, Super Columbine Massacre RPG!, and Battle Raper, on PC World's list of 15 most offensive digital games ever made (Peckham). Merging long-standing notions of militarism and enmification in the US public imaginary with mechanics and game affordances through retro sound and graphic references to the era of arcade gaming toward the end of the Cold War, Muslim Massacre begins with a simple yet compulsive mission of mechropolitics (Figure 1): "Take control of the American hero and wipe out the Muslim race with an arsenal of the world's most destructive weapons!" Following the overall logic of $1 \mathrm{X}$ war games, Muslim Massacre recites the taken-for-granted, yet far from simple, logic of necropolitical enmificationthe logic that states that the right to wage wars is simultaneously the right to take lives, to sanctify death en masse. Provocatively mechropolitical, Muslim Massacre casts America's latest out-group Other, that is Muslims, as a host of suicidal, erratic pixels on the screen. As soon as the game of "modern religious genocide" starts, players find themselves in a drone-eye-view position of extreme power vis-à-vis the US enemy's pixel-bodies, responding to Muslim terrorists' allegedly unfounded violent undertakings (against the United States) with a righteous necropolitical mission of death (in the interest of the United States). After all, to interact with the enemy forces in war, 1X games concur, is to rush to kill, often even before the Other has in any way assaulted the "self." 


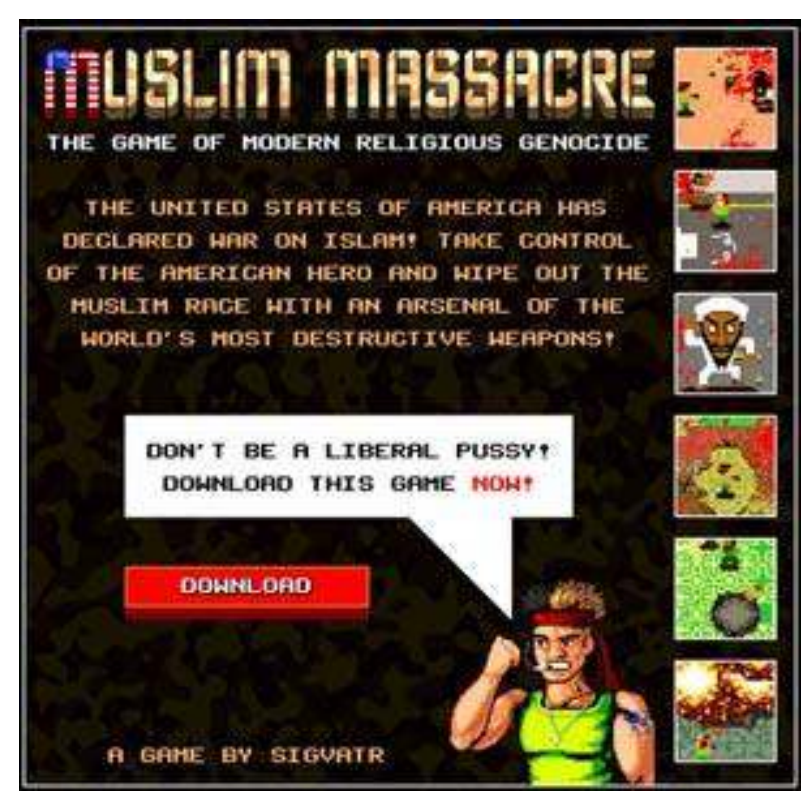

Figure 1: Muslim Massacre: The Game of Modern Religious Genocide, designed by Eric Vaughn, 2008.

In the game's "playground of mortality" (Phillips 138), it is the entire "Muslim race" (Vaughn) that is exterminated. This total mission of death is written into the game's ludic scenario, where-subscribing to murkily predetermined narratives of enmification whose history we do not know (and we have been instructed not to bother too much about)-the injustice of death by/because of religion (ethnicity, or other factors) gets distributed justly and indiscriminately. In its mediocre yet unapologetic show of mechropolitics, Muslim Massacre dispatches a hypermasculine soldier, the outof-place relic of the pre-drone wars of the previous centuries, to "the desert"-that unmapped, "uncivilized," safely remote edge of enmification-to act on behalf of the sovereign. Once there, he then gives out death all the way up the ladder that leads to the enemy's religious guide, i.e., its prophet, and its divine source of faith, i.e., its god. In this sense, then, Muslim Massacre is not only a playground of mortality but also a playground of morality, where to kill or not, to let die or not, is a matter of both player morality and ludic affordances.

12 A thematic foil to Muslim Massacre is the critically acclaimed 2D open-end newsgame September $12^{\text {th }}$ : A Toy World (2003) that was designed by Gonzalo Frasca. ${ }^{4}$ Originally a timely, poignant critique of the US invasion of Iraq and Afghanistan, September $12^{\text {th }}$ has proved to stand the test of time as a ludic simulation that portrays the frenzied, twodecade long history of what is commonly referred to as the "War on Terror." In an article for the New York Times, Clive Thompson describes the game (which is also the first example of what has come to be known as newsgaming) as "an op-ed composed not of words but of action." Freely available online, September $12^{\text {th }}$ is in fact a simulated war editorial which, while interactive, offers little variation in its visual coverage and its views on developments at the battlefront. Joining other anti-war games such as Bushgame: The Anti-Bush Video Game (2004) and Antiwargame (2001), September $12^{\text {th }}$ presents a prominent platform to both reflect upon and contest the out-of-hand necropolitical motives behind the post-9/11 US foreign policy, as well as the globalizing force of the so-called Islamist terrorism, parties to which seem to have multiplied over 
time beyond clear markers of nationality, religion, ethnicity, or geography. As a newsgame, it is a rendezvous spot where "simulation meets political cartoons" (Frasca).

Bringing an entirely different take on necropolitics to the gameworld, September $12^{\text {th }}$ presents its players with a simple choice: either to choose to exterminate the Muslim enemy and then face a resounding failure in the attempt to terminate terrorism or, as a matter of principle, to avoid playing altogether (Figure 2). Choosing to join the necropolitical state and let it kill both terrorists (who the game presents as men wearing a keffiyeh and a firearm) and civilians (seemingly unarmed, fully covered women and barefooted children), the game warns, would in turn further mean agreeing to the less blatant, less visible, yet more harrowing work of necropolitics, that is, to let (civilians) die. Beyond denouncing necropolitical structures of enmification and condemning players' complicity in the work of the state, however, the game does cultural work best when it cautions about the farcical nature and ultimate failure of the necropolitcal apparatus in the age of drone wars and in the face of the resurrecting and multiplying enemy. In this regard, the game's work is particularly constructive as it reminds, in Ronak K. Kapadia's words, of " $[\mathrm{t}]$ he differential powers of the US military over precarious life and death, freedom and suffering, recognition and obliteration"powers that employ "new technologies of surveillance that seek to enclose suspect humanity within its aerial view" (2).

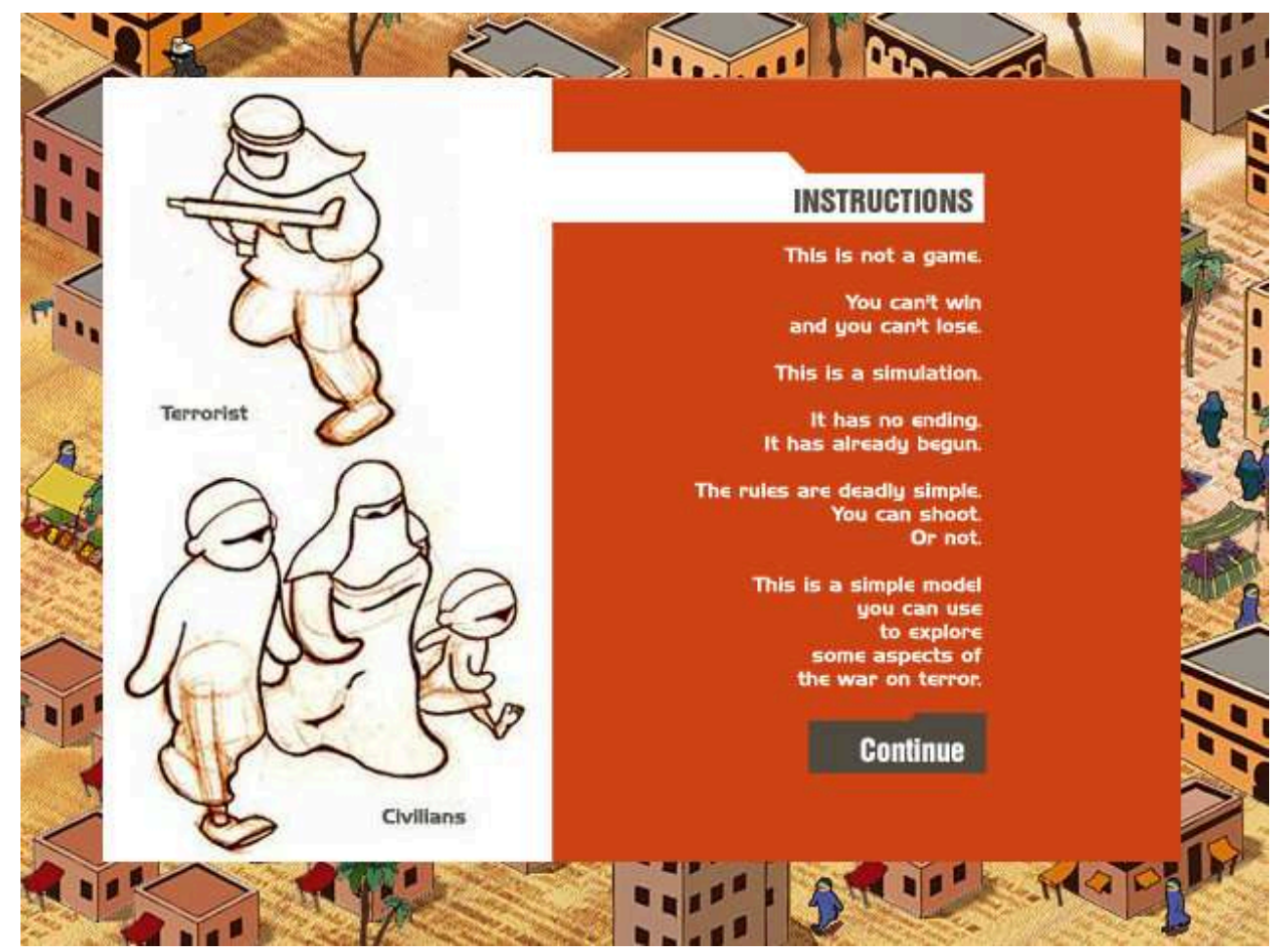

Figure 2: September 12th: A Toy World, designed by Gonzalo Frasca, 2003.

This results from the game's use of what I call the "instant reincarnation" effect. Following this effect, almost at the same time that a missile attack kills civilians and terrorists, mourning women transmute into terrorist men and hold arms, right there and then. September $12^{\text {th }}$ 's resurrecting enemy, civilian or terrorist, male or female, is thus an adversary encore. After having played the online game for just a few minutes, players realize that they have stepped into a nightmare in which killing the Muslim enemy results not only in more destruction and deaths but, more significantly, in the 
rise of more enemies and in the desperate need for exercising ever more forceful necropower. Deflating mechropolitics' promise to turn death into procedural fun, this 1X game in fact lingers the longest on the madness of war, on the litany of death that the necropolitical state unleashes, both in the gameworld and in reality, at the same time that it questions necropower as enmification's end.

If Muslim Massacre hands out morally disengaged invitations to join its blasé necropolitical project, take up arms, and act as the "American hero" to kill the Muslim enemy in its pest-like genericity, September $12^{\text {th }}$ disinvites players, rather forcefully, from entering the dreadfully dull, mechropolitical simulation that it is. Taken together, however, these games construct the US enemy in a dim, ambiguous light. In both games, the 9/11 events and anything that happened during the decades and centuries preceding them seem to have been relegated to the taken-for-granted package of "already known" and "already agreed upon" starting points in which the logic of a great majority of war games is rooted. Neither of the games (even September $12^{\text {th }}$ with the counter-narrative anti-necropolitical mission that it sets out for itself) code Muslims as crafty, dangerous adversaries against whom a mix of violence and valor is essential. Nor do they resort to the mystifying conventions of Orientalism, depicting Muslims as "pixel pashas" or as cohabiting with "digital djinns" (Reichmuth and Werning 45). Instead, and this I will expand on in the following pages, they render them as (repulsively) racialized: despicable, erratic, unfamiliar beings of no past (hence no selfhood) who can be erased from the game script with the least effort necessary. Complementing historical erasure with racialization, they represent this enemy either as an unworthy, easy/ready/deserving-to-exterminate, worthless rabble of bugs in Muslim Massacre, or as a dangerously multiplying horde of pixel-bodies that lure players into a maddening killing spree that can never end in September $12^{\text {th }}$. In sum, to decide to play these games would involve joining a necropolitical race in which players click, as a result of which the racialized enemy moans, groans, and dies-or, worse, grows nightmarishly in numbers.

\section{Racialization, or Heedless Feasts of Indifference}

In his re-reading of Hannah Arendt, Mbembe asserts that "the politics of death" is both preceded and supplemented by "the politics of race" (17). In other words, racialization -rhetorical technologies and enmification processes through which the Other is marked for extermination as a collectivity of undesirable, illegible, threatening bodies -feeds back into necropolitics. In Muslim Massacre, racialization and the subsequent extermination (and ultimately the extinction) of "the Muslim race" surfaces too overtly too quickly to leave room for doubt regarding its anti-Muslim sentiments. In the deathworld it creates, the player is directed by the sovereign to embrace the US's imperial history "without blinking, flinching, or walking away" in the sense that William Appleman Williams refers to (72). This feeling gives way in war games to assuming the role of "the American hero"-the heavily-armed, blond, Rambo-like hypermasculine warrior-who acts as a provisional member of the sovereign class, or more accurately, as its disposable pawn, its soldier, in order to enact the ultimate form of violence, that is, death, upon faceless, racialized Others. In the case of September $12^{\text {th }}$, on the other hand, we encounter a more complexly conceived bond between race and death. As game critics, like Ian Bogost and Patrick Crogan, agree, the game centers its 
(un)playability on "the rhetoric of failure" (Bogost 229)-a rhetoric rooted in its criticism of the out-of-hand consequences of responding to violence with violence. It is, in sum, an outstanding newsgame that follows its designer's belief in the necessity to transform the tenets of the "theater of the oppressed" into game design. ${ }^{5}$

And yet, when placed in broader conversations about what ties race and death, September $12^{\text {th }}$ 's vehement critique of US necropolitics (most directly conceived in the game's "verbal rhetoric" [Bogost 104]) right at the start of the game finds its place next to its other, less critical aspects. A mechropolitical reading of the game's visual/"procedural rhetoric" (Bogost 104) in fact sheds light on other, less overtly discussed aspects of September $12^{\text {th }}$ and its perception of the enemy image as it sets the spectacle of death caused by "the nonprecision weapons of U.S. "precision warfare" (Bogost 102). As mentioned before, as soon as the game is played, the "instant reincarnation" effect is triggered: subsequent to each missile attack in the game's "toy world," the terrorists' becoming corpses is synchronized with the civilians' becoming terrorists. This way, September $12^{\text {th }}$ in fact diverts attention from Muslims as the oppressed and the traumatized victims of the war by instead representing them as implicitly extremist and impulsively violent. Though troubling to concede, and whether done intentionally or unintentionally, the newsgame is in the end informed by a mediascape that has helped build and normalize both fear toward Islam as an ideology (Islamophobia) and hatred for Muslims' "brown" bodies (anti-Muslim sentiments) as a historical, yet current narrative clash of selfhoods. ${ }^{6}$ Diverting attention from Muslims as its ultimate victims, this tangle of fear and hatred toward Islam and Muslims has ended up in the post-9/11 climes to be understood, not as a crisis that implicates Muslim communities and cultures as evil Others, but rather as "a conflict over American identity" (Ernst 3; emphasis added). Resonating, in part, with this shift of attention, the game focuses more on the excessive exercise of necropower in US foreign policy than it does on Islamophobia as a necropolitical attempt on Muslims' lives and a conflict over Muslims' identity and livelihood.

Eventually, in its inadvertent deferral of the critical attention that the racialized US enemy is due, September $12^{\text {th }}$ stops short of even vaguely alluding to the diverse responses the oppressed have had to the war on terror. In other words, in its exclusive focus on the necropolitical doings of the state (and the empire), it inevitably writes off the fact that, once attacked and their home occupied, Muslim (but also non-Muslim) communities-citizens of a number of geographically proximate, yet distinct nationsreacted to the evil of war in myriad different ways: No doubt, some had no choice but to flee and live as stranded refugees, while others decided to stay and fight against the spread of terrorism. Some chose to join their country's official army to fight against the foreign occupying forces while others resorted to cultural work against violence. In a culture saturated in the rhetorical vilification of this enemy, the game does not take issue with the Islamophobic frame Americans have gotten used to over the past two decades. Far from that, September $12^{\text {th }}$ concedes (or at least does not object to the assumption) that certain groups of people, with a specific phenotype and inhabiting a specific spot on the world map-in other words, the racialized Others-decide in the face of crisis to resort to extremism and to become terrorists. Overall, this counternarrative game brims with ideological tension as it slams the necropolitical foundations of the war on terror and yet does not distance itself effectively and 
meaningfully enough from the commonly racialized, disproportionately generalized images of the Muslim enemy in the post-9/11 US popular imaginary.

But how do necropolitics and racialization come together in 1X digital games? Racialization is a structural, collective desire to submit the already marked other to varying degrees of violence and bestialization. It is a bodily expression of joy or, as Donovan Schaefer asserts, "the heady thrill that comes from walling people off" (123). It In an incisive comment on the collective, universal force of racialization across the board, Schaefer makes sense of racialization in terms of affect: "The cause of a nation, a pack of bodies, reorients itself (from pre-Civil War Yugoslavia to mid-1980s Argentina to the United States after 9/11) toward a shared affective expression. Bodies experience a 'passionate yearning' for the glorious cause of us against them" (130). Mechropolitics transforms this affective yearning into a ludic desire and a technical ability to exterminate. After all, "racialized ideology" is itself "a feast, a game [to] play" (Schaefer 128). Playfully racialized, then, simple war games such as $1 \mathrm{X}$ titles espouse reductionist, necropolitical forms of violence into their gameplay by scripting violence through ambiguous representations of a paradoxically constructed, militant yet mediocre, enemy. In the case of Islamophobia, for instance, the systematic reduction of religion to race, or as Carl Ernst points out, to "a political movement aiming at the imposition of the sharia law in America" (4), renders Islam as unworthy of the First Amendment right to freedom of religion. The evident structural rupture introduced to the reception of Islam as a religion vs. Islam as a race vs. Islam as a political project has direct bearing on the perception of Islam in the United States, resulting in further ambivalence and confusion toward followers of Islam (as well as toward Muslimlooking folks). Consequently, the US government rejects Islam's privileges as a religion, thus presenting Muslims not as a people of faith but as brainwashed victims of a social ailment, or worse, an ideological plague.

In light of this ambivalence, America's racialized enemy is sketched as a particularly expendable enemy. Muslim enemies matter in Muslim Massacre and September $12^{\text {th }}$ only in so far as they are at once external and extraneous to American identity and as long as they give shape to that identity without standing as an entity in and of themselves. They are relevant only as ludic matter-what drives the game and dictates its aesthetics -but not as an element that decides the game's success in the market and determines its politics. To take the example of the deicidal Muslim Massacre, for instance, we see that, in distributing death rather indiscriminately, it views Muslims neither with fear nor with fascination. It in fact echoes a larger culture of enmification that, deeply obsessed with drawing ever more convincing enemy images, has long ceased to "see" its enemies. Taking the pragmatics of necropolitics a step further, it is a game in which we learn how to choose to close our eyes. In our age of hyper-surveillance, Muslim Massacre reminds us that we, as a collectivity, are tired of looking closely at the screen, the breaking-news coverage, the recording in front of us. Indiscriminate killing, both in necropolitical states and in its mechropolitical renderings in video games, is therefore coupled with an ideologically induced sensory fatigue: we can see and surveille the threatening Other ever so closely, ever so often, that we opt to do the opposite-to not see, to not look.

21 A guaranteed achievement of any necropolitical apparatus lies in fact in its success in inverting hyper-visibility into in-visibility and indifference, where looking overtly is transformed into overlooking, before and while unseeing gives free rein to genocidal 
sentiments. Either as soldiers or as players, we can kill a whole lot of people (or agree that the necropolitical constituency kills on our behalf) only once we stop looking at our enemies' faces, once we cease to think of them as individuals with bodies and stories. This, in sum, is racialization at its most effective: reduced, uninterested, commonplace. As a result, then, what in these ludic encounters strikes least is that the Muslim enemy is at the mechropolitical mercy of the players' fingertips as they maneuver around the game space with the mouse or the joystick and click them dead.

In light of the affective bond between players and games, I argue, it is racialization coupled with indifference that allows Muslim Massacre to find a place in the margins of the gaming industry and prompt a response out of it. The same odd pairing turns September $12^{\text {th }}$ into a non-immersive, non-narrative gaming experience-designed to be played not for fun but for reflection, or not played at all. As Frasca himself maintains, "[w]e will not see critical videogames until major games are developed by biased authors that understand that fun is not the only thing that could be conveyed through this medium" (89). Merging the contradictory forces of difference and indifference in one, these games serve as ludic cameos-extremely short narrative forms that, while shorter than their $4 \mathrm{X}$ counterparts, are no less revealing of the hedonistic hoo-ha and the ludic ritual at the heart of Islamophobia. In my reading of these games, then, to imagine Muslims as the supposedly exclusive enemy of the United States in our postCivil Rights, post-Cold War, post-9/11 times necessitates joining the rationalizing projects of racialization with mechropolitical missions of extermination. As such, $1 \mathrm{X}$ game such as September $12^{\text {th }}$ and Muslim Massacre modify our understanding of racialization in terms both of projects that mark differences and relish them, what Sharon Patricia Holland phrases as "the American feast of difference" (6), and of projects that ludify a deeply affective sense of indifference toward who gets targeted by necropolitics and why-what I understand as heedless feasts of indifference.

\section{Concluding Remarks}

The typology of enemy images and the necropolitical responses of the increasingly militarized US politics and culture to each and every type of enemies have enjoyed such omnipresence that we can hardly talk of a (necro)political "turn" in US popular culture the same way that we talk about the forensic, the visual, or the spatial turn. However, in bringing the study of US pop culture closer to the reading of war games, this essay joins critical game studies in advocating the necessity to study the necropolitical through the ludic. In so doing, I focused here on two $1 \mathrm{X}$ digital war games that reflect and engage with the enmification narratives that post-9/11 US popular culture has given shape to. Stepping away from oft-analyzed AAA games, I examined two simple video games of recent years that, while marginal and blatantly easy and absurd to play, posit American and, by extension, global gamer communities vis-à-vis Muslims as their computer-controlled enemies and try (and in the case of September $12^{\text {th }}$ purposefully fail) to curb the imagined threat that they pose to the United States.

24 As discussed above, these games allow for the direct yet unequal confrontation of warriors/soldiers/heroes and "terrorists" at the same time that, in placing disproportionate attention on the American side of the war scenario, they make it impossible to reflect on what terrorism actually means and who is a terrorist. The $1 \mathrm{X}$ games under study here bar any form of knowledge, even speculation, about the 
ideological backdrop and the historical scenarios against which Muslims-postcolonial, stranded, generic, and yet equally dangerous and worthless-have been turned into terrorists as the enemies of the United States at the dawn of a new century. As Richard Jackson asserts, 'like 'freedom,' 'democracy' and 'justice,' 'terrorism' now functions as a primary term for the central narratives of the culture, employed in political debate and daily conversation, but largely unquestioned in its meaning and usage" (394).

In the post-9/11 political climate that is characterized by "the blurring of the real and the unreal" (J. Holland 1), Muslim Massacre and September $12^{\text {th }}$ center our understanding of necropolitics on racialized enmification. This form of racialization (as any other form of it) consists, Schaefer tells us, of "the hedonicity of hate, the desire to cast scorn, the lush, self-absorbed pleasure in erasing another body's face” (123). As I suggested before, the reductionist, simplified playscript of these 1X games sends a rather uncomplicated message about the twenty-first-century Islamophobia-Islamophilia spectrum of racialization onto which Muslim Others are being etched. They are perceived, rather ambiguously, as an alienated mass of beings whose fate is in the hands of the American hero. When framed as the enemy of the United States, Muslims are depicted as a racialized nuisance, pests that the American hero can get rid of in no time, in the case of Muslim Massacre, and as a less-than-worthy racialized and gendered enemy who is better left alone because, if not, it would keep multiplying itself (inevitably into more terrorists), in the case of September $12^{\text {th }}$. The games' mechropolitical scenarios work thanks to the way Islamophobia-thanks to its strong hedonistic primatological essence-diverts attention from Islam and Muslims in order, in fact, to present it, even in a critical game such as September $12^{\text {th }}$, as an American problem. As post-9/11 war games conjure Muslims as ludic matter, the enemy image they promote is racialized through an oxymoronic confluence of marking differences and killing indifferently. In light of such necropolitical indifference, it is evident that the absurdly intimate, affective, yet normalized nature of mechropolitical experiences and their bond to real-world necropolitics have ceased to fascinate players as the popular meets the political in the palms of their hands.

To conclude, I would like to maintain that discussing shoot-'em-up, 1X digital games in conversation with racialization serves at least two urgent purposes in the broader conversations made in the present special issue: First, dismissed as commonplace, large and small digital games are in fact the most successful, appealing, and ubiquitous of pop-cultural texts available to us to consume, read, work with, modify, and learn from, cultural artifacts that render visible a tangle of relations between human bodies and intellect, software and hardware, codes and colors, tones and texture, and the more abstract ideas, ideologies, and aesthetics that go into cultural production in the twentyfirst century. Secondly, similar to Islamophobia that is affective in targeting othered, "colored" bodies, digital games are technosocially and ideologically affective systems that let players feel the many emergent ways of being in the world as they hunt down enemies in secret, dark hideouts in mechropolitical missions of extermination, grapple with the bodily sensations of terror and heightened heart rate when playing horror games, or pass rather ambivalently through carefully distributed regimes of labor and leisure that are determined by the neoliberal order of capital and commodification in the twenty-first century. 


\section{BIBLIOGRAPHY}

America's Army 3. United States Army, 2009.

Antiwargame. Futurefarmers, 2001.

Appleman, Williams William. "Empire as a Way of Life." Radical Historical Review, vol. 50, 1991, pp. 71-102.

Arjana, Sophia R. Muslims in the Western Imagination. Oxford: Oxford UP, 2015.

Bogost, Ian. Persuasive Games: The Expressive Power of Videogames. MIT P, 2007.

Brady, Sara. Performance, Politics, and the War on Terror: "Whatever it Takes." Palgrave Macmillan, 2012.

Bushgame: The Anti-Bush Video Game. Starvingeyes Studios, 2004.

Crogan, Patrick. "War, Mathematics and Simulation: Drones and (Losing) Control of Battlespace." Zones of Control: Perspectives on Wargaming, edited by Pat Harrigan and Matthew G.

Kirschenbaum, MIT P, 2016, pp. 641-67.

Emrich, Alan. "MicroProse' Strategic Space Opera is Rated XXXX! A Revealing Sneak Review." Computer Gaming World, vol. 110, September 1993, pp. 92-93.

Ernst, Carl W. Islamophobia in America: The Anatomy of Intolerance. Palgrave Macmillan, 2013.

Foucault, Michel. “Society Must Be Defended." Lectures at the College de France 1975-76, edited by Mauro Bertani and Alessandro Fontana, translated by David Macey, Picador, 2003.

Frasca, Gonzalo. Videogames of the Oppressed: Videogames as a Means for Critical Thinking and Debate. 2001. Georgia Institute of Technology, MA thesis, 2001.

Gottschalk, Peter, and Gabriel Greenberg. "Introduction to Second Edition." Islamophobia and AntiMuslim Sentiment: Picturing the Enemy. Rowman and Littlefield, 2019, pp. 1-10.

-----. Islamophobia: Making Muslims the Enemy. Lanham: Rowman and Littlefield, 2008.

Holland, Jack. Selling the War on Terror: Foreign Policy Discourses After 9/11. Routledge, 2012.

Holland, Sharon Patricia. The Erotic Life of Racism. Durham: Duke UP, 2012.

Jackson, Richard. “Constructing Enemies: 'Islamic Terrorism' in Political and Academic Discourse." Government and Opposition, vol. 42, no. 3, 2007, pp. 394-426.

Kapadia, Ronak K. Insurgent Aesthetics: Security and the Queer Life of the Forever War. Durham: Duke UP, 2019.

Khabeer, Su'ad A. Muslim Cool: Race, Religion, and Hip Hop in America. New York UP, 2016.

Mbembe, Achille. "Necropolitics.” Translated by Libby Meintjes, Public Culture, vol. 15, no. 1, Winter 2003, pp. 11-40.

Muslim Massacre: The Game of Modern Religious Genocide. Eric Vaughn, 2008.

Nieuwkerk, Karin, Mark LeVine, and Martin Stokes, editors. Islam and Popular Culture. U of Texas P, 2016.

Omidvar, Iraj, and Anne R. Richards, editors. Muslims and American Popular Culture. ABC-Clio, 2014. 
Peckham, Matt. “The 15 Most Offensive Video Games Ever Made.” PC World, 29 September 2010, https://www.pcworld.com/article/206555/

the_15_most_offensive_video_games_ever_made.html. Accessed 1 Feb. 2021.

Phillips, Amanda. "Shooting to Kill: Headshots, Twitch Reflexes, and the Mechropolitics of Video Games." Games and Culture, vol. 13, no. 2, 2018, pp. 136-52.

Rane, Halim, Jacqui Ewart, and John Martinkus. Media Framing of the Muslim World: Conflicts, Crises and Contexts. Palgrave Macmillan, 2015.

Reichmuth, Philipp, and Stefan Werning. "Pixel Pashas, Digital Djinns." ISIM Review, vol. 18, 2006, pp. 45-47.

Robertson, Allen. America's Digital Army: Games at Work and War. U of Nebraska P, 2017.

-----. “The Unreal Enemy of America's Army.” Games and Culture, vol. 6, no. 1, 2011, pp. 38-60.

Schulzke, Marcus. “America's Army.” Zones of Control: Perspectives on Wargaming, edited by Pat Harrigan and Matthew G. Kirschenbaum, MIT P, 2016, pp. 303-08.

Schaefer, Donovan O. Religious Affects: Animality, Evolution, and Power. Duke UP, 2015.

September $12^{\text {th }}$ : A Toy World. Newsgaming, 2003.

Thompson, Clive. "Saving the World, One Video Game at a Time." New York Times, 23 July 2006, https://www.nytimes.com/2006/07/23/arts/23thom.html?pagewanted=all\&_r=0. Accessed 1 Feb. 2021.

Wardrip-Fruin, Noah, and Pat Harrigan, editors. First Person: New Media As Story, Performance, and Game. MIT P, 2004.

Wiegand, Krista E. "Islamic Terrorism: The Red Menace of the Twenty-First Century." The Impact of $9 / 11$ on the Media, Arts, and Entertainment, edited by Matthew J. Morgan, Palgrave Macmillan, 2009, pp. 51-62.

\section{NOTES}

1. I wish to thank Elena Furlanetto and Mahmoud Arghavan at whose panel on Islamophobia at the DGfA annual conference (Hamburg 2019) I presented a first draft of the present essay. I also wish to thank the anonymous reviewers whose comments helped me improve the essay in substantial ways.

2. For recent, fine-grained studies on the question of Islamophobia and US popular culture, see, among others, Muslims and American Popular Culture by Iraj Omidvar and Anne R. Richards; Islam and Popular Culture by Karin Nieuwkerk, Mark LeVine, and Martin Stokes; Su'ad A. Khabeer's Muslim Cool: Race, Religion, and Hip Hop in America; and Peter Gottschalk and Gabriel Greenberg's Islamophobia: Making Muslims the Enemy. More broadly, titles such as Halim Rane, Jacqui Ewart, and John Martinkus's Media Framing of the Muslim World: Conflicts, Crises and Contexts and Sophia R. Arjana's Muslims in the Western Imagination touch upon the global dimensions of Islamophobia beyond the borders of the United States.

3. Currently, the game's website is replaced by a Japanese porn service-provider, a space of taboo and tension where two groups of seemingly antipodal yet victimized bodies are layered on top of one another in one and the same virtual site: the othered, dismissed, and demonized pixel-bodies of the Muslim enemy in the game seems to have been replaced, this time, by the othered, fetishized, and desired bodies of Asian prostitutes and porn stars-both of which are laden with discomforting affect and charged with lustful ambivalence. 
4. The game can be accessed and played freely at http://www.newsgaming.com/games/ index12.htm.

5. Frasca first discussed his views on the necessity to design games that go beyond fun and toward critical thinking in his MA thesis "Videogames of the Oppressed: Videogames as a Means for Critical Thinking and Debate."

6. In the introduction to the second edition of their 2008 book Islamophobia and Anti-Muslim Sentiment: Picturing the Enemy, Gottschalk and Greenberg distinguish between Islamophobia as "a social anxiety toward Islamic traditions and Muslim-majority cultures that is largely unexamined by, yet deeply ingrained in, Americans" and anti-Muslim sentiments as "the rejection of certain types of bodies" ("Introduction" 4; emphasis in original).

\section{ABSTRACTS}

Graphically and narratively simple war games such as the critically acclaimed, counter-narrative September $12^{\text {th }}$ (2003) and the heavily criticized and deleted Muslim Massacre (2008)-titles that I refer to as $1 \mathrm{X}$ war games-trade in the overall logic of necropolitics. I refer to these games as $1 \mathrm{X}$ because, in encountering America's enemies, they promote only the last of the $4 \mathrm{X}$ game-verbs, that is, "eXterminate." In other words, instead of planning how to best train for, track down, encounter, and ultimately fight against this enemy, the choice that these controversial, post-9/11games offer is to simply eliminate the already out-at-large, under-armed, erratic Muslim enemy in a drone-like, distanced, and lackluster manner. As I suggest in this essay, 1X games promote unappealing and non-immersive, yet overtly political projects of death. Adopting Achille Mbembe's notion of necroplitics in the ludic, mechropolitical sense proposed by Amanda Phillips, I focus on these games' opposing, yet usefully comparable, approaches to enmification through racialization through entertainment-a two-step project of death that, nodding to Sharon Patricia Holland, I understand as affective, yet heedless feasts of indifference.

\section{INDEX}

Keywords: US Popular Culture, Necropolitics, Mechropolitics, Racialization, Racial Affect, 1X Games, Critical Game Studies

\section{AUTHOR}

\section{MAHSHID MAYAR}

Author of Citizens and Rulers of the World: The American Child and the Cartographic Pedagogies of Empire (forthcoming with the University of North Carolina Press), Mahshid Mayar [she/her] is an assistant professor of American Studies at Bielefeld University, Germany. In her current research, Mahshid interrogates the politics and poetics of silence and silencing in a book project that attends to the political, the historical, and the aesthetic in 21C US erasure poetry. Her research and teaching interests lie in protest poetry, new empire studies, historical childhood 
studies, 19C US history, and critical game studies. Currently, Mahshid is a research associate at the English Department, Amherst College, Massachusetts. 